\title{
The Effect of Regional Government Size, Legislative Size, Number of Population, and Intergovernmental Revenue on The Financial Statements Disclosure
}

\author{
Nuriska Gusnaini, Ronny Andesto, and Ermawati
}

\begin{abstract}
This study intends to discover the disclosure level of local government financial statements regarding the local government size, legislative size, population, and intergovernmental revenue. This study uses the Regency / City Regional Government in East Java Province in 2016-2018. Census sampling method which is $\mathbf{1 1 4}$ samples in the District / City Government in East Java Province is applied. The hypothesis testing in this study is multiple linear regression with SPSS. The results of this study are that the size of the regional government and the size of the legislature have no effect on the financial statements; the population has a significant effect on the financial statements, and the intergovernmental revenue has a significant effect on the financial statements of the local government. This study contributes to providing suggestions to improve the quality of local government financial reports.
\end{abstract}

Index Terms - Size of Local Government, Legislative Size, Intergovernmental Revenue, Level of Disclosure.

\section{INTRODUCTION}

Good governance is closely related to the existence of authority to implement regional autonomy. It is about how the government is able to run its own governance and can account for the budget well. According to [27] concerning Local Government, each regional government - the regional, district and city governments should make their own financial statements. In addition, it is stated in [26] about state finances that state finances are managed to be obedient to the laws and regulations. They aim to be effective yet efficient. They should be accountable, economical, and transparent as well.

Financial reports ought to be generated following the rules of Government Accounting Standards (SAP). Disclosure in the financial statements is also a very important thing used as a means by an organization both in the private sector and government. Adequate disclosures are required in the financial statements in order to be able to describe the actual condition of the local government during the accounting period. The government has issued a policy in PP should also present quality which is relevant, reliable, comparable, and understandable for the users. Therefore, the disclosure of financial statements is essential to be implemented by local governments [10].

In reality, it is possible that BPK still discovers several findings related incomplete disclosure of the presented financial statements. Although in some areas, most financial statements have obtained the results of the Fair Unqualified

Published on December 15, 2020

Nuriska Gusnaini, Universitas Pembangunan Nasional Veteran Jakarta, Indonesia.

(e-mail: nuriskag@gmail.com)
Audit opinion (WTP). In this case, even though the Regency /City LKPD in East Java Province has received WTP opinion, there are some facts found. First, it is the Internal Control System which has not been arranged. Second, the laws and regulations compliance which are unrelated to the provisions. They prove that the regional government has not been able to declare the financial statements of the local government which are related to the applicable laws and regulations. One of the mandatory disclosures in the financial statements has not been disclosed in full.

In Indonesia, the problem of disclosure also receives support from several studies conducted, and the results conducted are still widely found that the government financial statement disclosures remain low in some areas. The average disclosure of Notes to Regional Government Financial Report is $44.56 \%$ [12]. The average level of disclosure of District / City Local Government Financial Statements (LKPD) in Indonesia is 52.09\% [24]. [9] presents that the average level of disclosure of Local Government Financial Statements (LKPD) is 61\%. [11] discovers that the average level of disclosure in the Notes to the Regional Government Financial Reports is $41.7663 \%$. [8] agrees that the average level of disclosure of District / City Local Government Financial Statements (LKPD) in Central Java is $52 \%$. [5] finds that the disclosure rate is only $64.6 \%$. Furthermore, [3] finds that the level of financial statement disclosure mentioned only $64.96 \%$. [17] identify that the regional financial statement disclosure level is $82.7 \%$. The level of mandatory disclosure of regional financial reports is only $22 \%$ [15]. Whereas [18] find that the LKPD disclosure rate is $36.80 \%$.

Some factors are admitted to influence the disclosure of regional financial statements. The first factor is the size of the regional government. It becomes the resource for the entity to carry out the operational activities. Greater assets affect greater resources for greater disclosures. The size of the legislature is measured by the number of DPRD members. DPRD has a role to oversee the running of local government activities so that the budget can be managed properly. The number of DPRD members is expected to be able to increase oversight so that it impacts with increasing performance of local governments. The population in an area can influence the local government to disclose their financial statements. The population reflects the complexity of government. This is because the greater the population, the greater the encouragement of the public to ask for greater disclosure in

Rony Andesto, Universitas Pembangunan Nasional Veteran Jakarta Indonesia.

Ermawati, Universitas Pembangunan Nasional Veteran Jakarta, Indonesia. (e-mail: ermawati@upnvj.ac.id) 
government financial statements. Intergovernmental revenue is one of the factors which affect the disclosure of financial statements. Intergovernmental revenue is a type of local government revenue. It comes from the central government which transfers to the local governments for finance operational activities. This study intends to determine the level of financial statement disclosure and the influence of local government size, legislative size, population, intergovernmental revenue and disclosure level of local government financial statements.

\section{LITERATURE REVIEW}

\section{A. Agency Theory}

Agency theory explains the relationship between two conflicting economic agents, principals and agents. If the principal and agent have the same goals, the agent should carry out the wishes ordered by the principal. [20] states that principals meet the needs of both facilities and funds to carry out company activities, whereas management as an agent has an obligation to manage what has been given by the principal. [3] states that there will be a conflict between the principal and the agent if the agent does not carry out what is ordered by the principal. That relationship has a problem in agency theory to face, namely asymmetric information (information asymmetries) and conflicts of interest.

\section{HYPOTHESIS DEVELOPMENT AND CONCEPTUAL SCHEME}

The size of local government is described by how many assets owned by the local government. It is also described by the size of the organization whether it is big or small. If the number of assets used is greater, the disclosure will be even greater [14]. Therefore, the more assets owned by local governments, the more they are required to make transparency in the management and maintenance of assets. It belongs to public accountability related to information in financial statement disclosures. Thus, local governments ought to pay high attention to the disclosures of government accounting standards. This shows that the greater the total assets owned by the local government, the greater the financial statement disclosures the local government should present.

$\mathrm{H}_{1}$ : The size of the local government has a significant effect on the level of LKPD disclosure

The Regional House of Representatives (DPRD) has a role as a legislative body in the Indonesian government. DPRD is a regional representative institution which oversees the implementation of local government due to the well-managed own budget [2]. [29] concerning Regional Government states that the DPRD has the duty and authority to elect, appoint and dismiss regional heads. The legislative has a relationship with the community. It is because the DPRD is chosen by the community as a regional representative so that the public expects open supervision in operational activities and financial management. It will be conveyed through disclosure of financial statement information. This proves that if the number of legislative members is greater, the level of oversight carried out by legislators will be greater as expected.

$\mathrm{H}_{2}$ : Legislative size has a significant effect on the level of LKPD disclosure.

According to [28], it states that the size of the population reflects the large need for public service provision in each region. It is explained that greater population affects greater community demands in which the local government carry out government activities and allocate budgets more transparently. It is also mentioned that the greater population affects the greater community's urge to demand higher information disclosure in the local government financial statements.

$\mathrm{H}_{3}$ : Population has a significant effect on the level of LKPD disclosure.

Intergovernmental revenue is described as a certain type of regional income from the central government to finance the local governments' operational activities [21]. The central government gives confidence to regional governments to manage their own government to realize decentralization. Therefore, local governments are required to account for the entire budget of the central government and the activities carried out by making full disclosure related to information to present their financial statements. It is done aiming that the central government is able to observe the local government activities. This shows that a greater level of dependency creates a greater level of financial statement disclosure by the local government. Then the hypothesis is formulated as follows:

$\mathrm{H}_{4}$ : Intergovernmental revenue has a significant effect on the level of LKPD disclosure.

\section{RESEARCH METHOdOLOGY}

The financial statements of local governments (LKPD) in East Java Province become the population in this study. In detail, there were 29 regencies and 9 cities in the 2016-2018 fiscal year. A census sampling method was applied. It produced 114 samples consisting of 38 districts / cities during 2016-2018. However, after the outlier data, 104 samples were used. The multiple linear regression analysis with SPSS was to test the hypothesis. The dependent variable came from the disclosure level of local government financial statements measured using a scoring index adopted by [17] and [19]. The independent variable was the local government size as measured by the total assets transformed into natural logarithms according to [8]. The legislative measures were measured using the number of DPRD members according to [18]. Then, the total population was measured by using the population in accordance with [3], and intergovernmental revenue was measured by comparing the total central government balance funds and total revenue multiplied by $100 \%$ according to [16].

\section{RESULTS AND DISCUSSION}

\section{A. Descriptive Analysis}

Based on the census sampling method, there were 114 samples consisting of 38 districts / cities during 2016-2018. However, after the outlier data were carried out, the samples 
used in this study became 104 samples. The descriptive statistical test results indicate that $80.42 \%$ is the disclosure level average of financial statements of Local Governments in East Java. The highest level of financial statement disclosure is mentioned $88 \%$ which was found in Jember Regency 2016, Situbondo Regency 2017, Sidoarjo Regency 2017, Probolinggo Regency 2018, Banyuwangi Regency 2016 and 2018. As for the lowest value, the level of disclosure of local government financial statements is equal to $58 \%$ found in Ngawi Regency 2017 and 2018. This means that the disclosure level of local government financial statements is quite high. Nonetheless, the local governments in East Java Province making mandatory disclosures of $100 \%$ are not discovered. The level of LKPD mandatory disclosure by previous studies greatly varies from $22 \%$ [15] to $82.7 \%$ [17]. The possibility in this study is influenced by the implementation of PP No. 71 Year 2010 [22]. In regard to the independent variable, the local government size has shown an average value of 28,91350 ; the legislative measure has an average value of 43.69; the population has an average value of 1038277.36 and intergovernmental revenue has an average value of 0.65378 . The results of the descriptive statistics are shown in Table 1 below.

\begin{tabular}{cccccc}
\multicolumn{7}{c}{ TABLE I: RESUlTS OF DESCRIPTIVE STATISTICS } \\
\hline Variable & $\mathrm{N}$ & Min & Max & Mean & SD \\
\hline DL & 104 & 0.58 & 0.88 & 0.8042 & 0.059 \\
LGS & 104 & 28.034 & 31.387 & 28.91350 & 0.611 \\
L & 104 & 25 & 50 & 43.69 & 8.475 \\
P & 104 & 126404 & 2885555 & 1038277 & 681343 \\
IR & 104 & 0.245 & 0.811 & 0.65378 & 0.096 \\
Valid N & 104 & & & & \\
\hline
\end{tabular}

\section{B. Results}

The results of the hypothesis testing of this study can be seen in Table 2.

TABLE II: TeSTING OF HyPOTHESIS OF DESCRIPTIVE STATISTICS

\begin{tabular}{ccc}
\hline \multicolumn{3}{c}{ Coefficients' } \\
\hline Model & $\mathrm{t}$ & Sig. \\
\hline 1 (Constant) & -0.649 & .518 \\
DL & -0.29 & .773 \\
L & -0.265 & .792 \\
P & 2.001 & .048 \\
IR & 2.778 & .007 \\
\hline
\end{tabular}

Table 2 below shows the regression test results indicating that the local government size individually gets a coefficient of -0.29 with a significance probability of 0.773 . Based on these results, it can be concluded that the regional government size delivers no effect on the disclosure level of local government financial statements. This study is not in line with [2], [13] and [18]. However, this study is in line with [30], [1], and [16]. This is not in accordance with agency theory, this shows that the greater assets owned by an area cannot guarantee the higher disclosure of local government financial statements. Sometimes, local governments owning large total assets face difficulties in recording or managing their assets. It is because the problem will be more complex. Thus, it will create obstacles for local governments to disclose information. There are still some findings from the BPK related to asset management that have not been good.
The legislative measurement obtains a coefficient value of -0.265 with a significance probability of 0.792 which is greater than the significance level of $5 \%$. It can be said that the legislative size has no effect on the disclosure level of local government financial statements. This study is not in line with [24], [13], and [18] but it is in line with [2] and [14]. This study is not in accordance with agency theory due to the increasing number of DPRD members and the more difficult coordination process for government difficulties. The number of DPRD members also does not have an influence on regional performance, otherwise it is followed by an improved supervisory function and role. One example is the persistence of corruption cases from the DPRD which further strengthens the reason for the decline in performance of the regional government [14]. This can reduce public trust in legislators as representatives of the public to help supervise their financial allocations through disclosure of local government financial reports. Therefore, the number of DPRD members cannot guarantee an increase in the disclosure of regional financial statements. It is because the oversight in the financial statements rely not only on the number of legislative members but also on the quality of DPRD members.

The population has a calculated $t$ value of 2.001 with a significance probability of 0.048 . It is summarized that the population has a significant effect on the level of disclosure of local government financial statements. This study is in line with [11], [25], and [4]. This study is in accordance with agency theory, where the higher the number of the population, the more complex the local government will be. There will be more information to disclose in the local government financial statements. This is evidenced by the existence of [28] that the large number of populations will reflect the needs of various public service facilities. Therefore, a greater population causes a greater encouragement of the community to local governments to make greater disclosure of information of local government financial statements.

Intergovernmental revenue variable has a t value of 2.778 with a significance probability of 0.007 . It explains the intergovernmental revenue which significantly impacts the disclosure level of local government financial statements. The results of this study are supported by some from [23], [25] and [3]. This study is in line with agency theory in which the greater the intergovernmental revenue, the greater the disclosure of local government financial statements will be. This is because local governments get the transfer funds from the central government to carry out their operational activities. Thus, the central government will hold accountability in the form of more disclosure of financial statement information. The financial statement information is related to the allocation of funds that have been given and to monitor the performance of local governments. In order to increase public confidence by not misusing funds that have been given from the central government, the transparency and accountability in financial management is created. 


\section{CONCLUSION, LIMITATIONS AND RECOMMENDATIONS}

This study aims to discover how local governments make disclosure levels in their financial statements regarding the factors affecting the size of local government, legislative size, population, and intergovernmental revenue. After doing a hypothetical analysis and testing, the conclusions drawn in this study are: The level of financial statement disclosure of regency / city governments in East Java Province is $80.42 \%$. The size of the regional government and the legislature deliver zero impact on the disclosure level of local government financial statements. However, both population and intergovernmental revenue significantly affect the disclosure level of local government financial statements.

This study has a limitation. The object of the study is limited to East Java Province. It has not been able to describe the overall disclosure level of local government financial statements. Only financial statements are used as the main source even though there are other sources, namely internal reports and quarterly reports. However, the main data source of financial statements is chosen because of the access. There are some suggestions for the central government. This study is expected to be an evaluation material in order to make policies to provide impetus for local governments. It is to increase the disclosure of local government financial reports and to carry out punishment and reward in accordance with SAP. For the local governments, it is to strengthen the legislative function to carry out the oversight function and improve the process of better recording or managing assets. For future study, it is hoped that they expand the object of study. It is advisable for them to explore other financial statement disclosure channels, such as on local government websites. It is better for them to add other variables outside such as the number of parliaments and internal auditors and add control variables. It will further strengthen the other studies suspected of having an influence on financial statement disclosures.

\section{REFERENCES}

[1] Adiputra, I. M. P., Utama, S., \& Rossieta, H. (2018). Transparency of local government in Indonesia. Asian Journal of Accounting Research, 3(1), 123-138.

[2] Agnecia, H., Simbolon, U., Kurniawan, C. H., Ekonomi, F., Atma, U., \& Yogyakarta, J. (2015). Pengaruh karakteristik pemerintah terhadap tingkat pengungkapan laporan keuangan pemerintah daerah di Indonesia. Accounting Analysis Journal, 4(2), 54-70.

[3] Amaliah, E. F. (2019). Analisis faktor-faktor yang memengaruhi tingkat pengungkapan laporan keuangan pemerintah daerah kabupaten/kota di provinsi Jawa Tengah tahun 2015-2017. Diponegoro Journal of Accounting, 8(2), 1-13.

[4] Andriani, M., Santi, E., \& Mustika, R. (2019). Faktor-faktor yang mempengaruhi tingkat pengungkapan laporan keuangan pemerintah daerah pada kabupaten/kota provinsi Sumatera Barat tahun anggaran 2014-2016. Akuntansi dan Manajemen, 14(1), 1-14.

[5] Arifin, J. (2018). Potential factors to enhance the level of disclosure within financial statements of Indonesian provincial governments. Jurnal Akuntansi dan Keuangan, 20(2), 89-98.

[6] Aswar, K., \& Saidin, S. Z. (2018a). Accrual accounting adoption in Java Municipalities: An empirical investigation. International Journal of Business and Economic Sciences Applied Research (IJBESAR). 11 (3). 24-30.

[7] Aswar, K., \& Saidin, S. Z. (2018b). The Influencing Factors On The Level Of Accrual Accounting Adoption: A Conceptual Approach. Romanian Economic Business Review, 13(2), 30-36.

[8] Budiarto, D. S., \& Indarti, L. (2019). Apakah karakteristik pemerintah daerah berpengaruh pada pengungkapan laporan keuangan pemerintah daerah? riset pada kabupaten di Jawa Tengah. Jurnal Akuntansi Bisnis, 12(1).
[9] Feriyanti, M., Hermanto, \& Suransi, N. K. (2015). Determinan kepatuhan pada ketentuan pengungkapan wajib laporan keuangan pemerintah daerah (Studi pada kabupaten/kota di provinsi Nusa Tenggara Barat). Jurnal InFestasi, 11(2), 171-185.

[10] Haryadi, E. S., Ratnawati, V., \& Kamaliah. (2015). Analisis pengungkapan (Disclosure) laporan keuangan kabupaten yang meraih opini audit wajar tanpa pengecualian (WTP) dua tahun berturut-turut. Akuntansi, 3(2), 184-195.

[11] Hendriyani, R., \& Tahar, A. (2015). Analisis faktor-faktor yang memengaruhi tingkat pengungkapan laporan keuangan pemerintah provinsi di Indonesia. Jurnal Bisnis Dan Ekonomi (JBE), 22(1), 25-33.

[12] Hilmi, A. Z., \& Martani, D. (2011). Analisis faktor-faktor yang mempengaruhi tingkat pengungkapan laporan keuangan pemerintah provinsi. Jurnal of Accounting and Public Police, 1-26.

[13] Keerasuntonpong, P., Dunstan, K., \& Khanna, B. (2015). Factors influencing disclosures of statements of service performance of New Zealand local authorities. Pacific Accounting Review, 27(3), 304-328.

[14] Khasanah, N. L., \& Rahardjo, S. N. (2014). Pengaruh karakteristik, kompleksitas, dan temuan audit terhadap tingkat pengungkapan laporan keuangan pemerintah daerah. Diponegoro Journal of Accounting, 3(3), 1-11.

[15] Lesmana, S. I. (2010). Pengaruh karakteristik pemerintah daerah terhadap tingkat pengungkapan wajib di Indonesia. Tesis. FE UNS. Surakarta.

[16] Liza, W. J., \& Arza, F. I. (2019). Analisis faktor-faktor yang mempengaruhi tingkat pengungkapan sukarela laporan keuangan pemerintah daerah. Jurnal Eksplorasi Akuntansi, 1(3), 959-977.

[17] Marsella, C., \& Aswar, K. (2019). An investigation of financial statement disclosure in local government financial statements. International Journal of Business and Economic Affairs, 4(6), 273 281.

[18] Maulana, C., \& Handayani, B. D. (2015). Pengaruh karakteristik, kompleksitas pemerintahan dan temuan audit terhadap tingkat pengungkapan wajib LKPD. Accounting Analysis Journal, 4(4), 1-11.

[19] Nurlianto, O., \& Aswar, K. (2020). A conceptual framework on the financial statement disclosure in Indonesia local government. Journal of Economics and Behavioral Studies, 12(3), 65-69.

[20] Pandansari, T. (2016). Tingkat ketergantungan, kompleksitas pemerintah, dan tingkat pengungkapan laporan keuangan pemerintah daerah. Jurnal Ekonomi Dan Bisnis, 19(3), 463.

[21] Patrick, P. (2007). The determinants of organizational innovativeness: The adoption of GASB 34 in Pennsylvania local government. May, 36.

[22] Peraturan Pemerintah (PP) Nomor 71 tahun 2010 tentang Standar Akuntansi Pemerintahan.

[23] Rafida, Ridwan, Abdullah, M. I., \& Yamin, N. Y. (2019). Pengaruh intergovernmental revenue, kekayaan pemerintah daerah dan umur pemerintah daerah terhadap tingkat pengungkapan laporan keuangan pemerintah daerah (Survei pada pemerintah kabupaten/kota di Sulawesi Tengah). Jurnal Akun Nabelo: Jurnal Akuntansi Netral, Akuntabel, Objektif, 1(2), 63-70.

[24] Setyaningrum, D., \& Syafitri, F. (2012). Analisis pengaruh karakteristik pemerintah daerah terhadap tingkat pengungkapan laporan keuangan. Jurnal Akuntansi Dan Keuangan Indonesia, 9(2), 154-170.

[25] Suryadi, P. T. (2018). Pengaruh kekayaan daerah (PAD), total aset jumlah penduduk, tingkat ketergantungan, dan temuan audit terhadap tingkat pengungkapan laporan keuangan pemerintah daerah. 1(1), 2130 .

[26] Law 17 tahun 2003 tentang Keuangan Negara.

[27] Law 32 tahun 2004 tentang Pemerintah Daerah.

[28] Law 33 tahun 2004 tentang Perimbangan Keuangan Antara Pemerintah Pusat dan Pemerintah Daerah.

[29] Law 23 tahun 2014 tentang Pemerintahan Daerah.

[30] Waliyyani, G. M., \& Mahmud, A. (2015). Pengaruh karakteristik pemerintah terhadap tingkat pengungkapan laporan keuangan pemerintah daerah di Indonesia. Accounting Analysis Journal, 4(2), 18 . 